\title{
Depression and Living Patterns in Old Age
}

\author{
Shamli Rana ${ }^{1}$, Shallu Rana ${ }^{2 *}$ and Chandra Kala Singh ${ }^{3}$ \\ ${ }^{1}$ Department of Human Development and Family Studies C.H.Sc, SKRAU Bikaner, India \\ ${ }^{2} \mathrm{COHS}, \mathrm{CCSHAU}$ Hisar, India \\ ${ }^{3}$ Department of Human Development and Family Studies, COHS, CCSHAU, Hisar, India \\ *Corresponding author
}

\begin{abstract}
A B S T R A C T
\section{Introduction}

Ageing is a continuous and irreversible phenomenon. With increase in average life span, it is also important that ageing should be healthy. It is also important that our societies should view the process of ageing positively. Individuals with a positive attitude towards old age are likely to live longer and in better health than those with a negative attitude. A global study conducted by Orb Media in over 101 countries and 1, 50,000 people to learn about their respect for older people. Pakistan was among those countries with highest score
\end{abstract}

\begin{tabular}{|c|c|}
\hline $\begin{array}{l}\text { Ke y w or d s } \\
\text { Depression, Living } \\
\text { patterns, Old age } \\
\text { homes, Family } \\
\text { system }\end{array}$ & $\begin{array}{l}\text { Greying of population can be viewed both as a concern as well as an opportunity. } \\
\text { Preparing in advance is the key to harvest the benefits of the vast experience and skill the } \\
\text { old population holds thereby contributing towards the building of nation. Countries } \\
\text { everywhere outside Africa are rapidly growing older. With the change in our economy } \\
\text { there comes the sea change in our traditional family system. In this era of globalization, } \\
\text { our budding generation is busy in their careers while parents are struggling alone with their }\end{array}$ \\
\hline Article & $\begin{array}{l}\text { age related issues. This study was conducted with the objective of unravelling the } \\
\text { relationship of living pattern with depression among elderly population. Samples were }\end{array}$ \\
\hline $\begin{array}{l}\text { Accepted: } \\
\text { 04 February } 2019 \\
\text { Available Online: } \\
10 \text { March } 2019\end{array}$ & $\begin{array}{l}\text { drawn equally from three settings i.e. those living with children, living alone and those } \\
\text { living in institutions like old age homes. The result highlighted that the depression } \\
\text { experienced by elderly living with children is reportedly least and highest in case of those } \\
\text { living alone. }\end{array}$ \\
\hline
\end{tabular}

reflecting the long standing tradition of respecting the older people.

According to World Health Organization, analysis $60 \%$ of people surveyed across 57 countries had negative views of old age. Adjusting to the changes that accompany old age requires that an individual is flexible and develops new coping skills to adapt to the changes that are common to this time in their lives (Warnick, 1995). Ageing is an inevitable developmental phenomenon bringing along a number of changes in physical, psychological, hormonal and the social conditions. Life expectancy in India has increased from 68 
years to an average of 68.3 years. With improvement in the average life years it is important that the considerable attention should be paid to the ageing population. At present our country comprises of relatively young population as $65 \%$ of our population is 35 or under and half of our population is under 25 year old. But slowly our demography is going to witness the phenomenon of "greying" which means ageing.

According to WHO definition, most developed world countries have accepted the chronological age of " 65 " years as a definition of 'elderly' or older person but there are many studies which consider the age of " 60 " for developing countries. The number of older people is increasing throughout the world. As individuals grow older, they are faced with numerous physical, psychological and social role changes that challenge their sense of self and capacity to live happily. Depression is considered to be the major problem leading to impaired quality of life among elderly persons. Many studies have demonstrated that the prevalence of depressive symptoms increases with age (Kennedy, 1996). Depression in old age creates many problems in carrying out activities of daily living. The major factor has found loss of a spouse, which takes a heavy toll on health and is one of the primary causes of depression.

Being left alone often prevents many older persons from enjoying life. Weissman et al., (1996) has observed that those who are divorced or separated are more likely to be depressed than those who are married. Attitudes toward the elderly have also been affected by large societal changes that have also been affected by large societal changes that have happened over the past 100 years. Researchers believed industrialization and modernization have contributed greatly to lowering the power, influence and prestige the elderly once held.
Chou and Chi (2000) found in their research on the older adult population in Hong Kong that elders who live alone, compared to those who live with others, perceive their health more negatively. The study also suggests that life satisfaction is lower for older adults living alone when compared to older adults in other community living situations. Ganatra et al., (2008) found depression level in females more than males and observed that depression in the elderly was significantly associated with being unmarried, not being employed, hearing impairment, dizziness, pain, mobility impairment, stress, fatigue, insomnia, visual impairment, higher number of health problems and inadequately fulfilled spiritual needs. Mubeen et al., (2012) found that depression was more among men than in women. Depression was statistically significant among married respondents and illiterate. Although a large proportion of the participants were satisfied with their income, this was statistically significant for depression among those who were not satisfied with their income. Similarly, sleep was significantly disturbed among the depressed respondents.

Rasquinha and Acharya (2012) conducted a study on elderly sample of 120 institutionalised and 120 non-institutionalized to find gender differences in depression. Geriatric Depression Scale was administered to the sample. The study concluded that institutionalized elderly are more depressed than non-institutionalized elderly and there is no difference in level of depression among male and female.

\section{Materials and Methods}

The study was conducted in the Panchkula district of Haryana. The said district was selected because the city has sufficient of number of old age homes to draw the sample from larger pool. The objective was to study the elderly residing in different settings i.e. with family, alone and in old age homes. 
Participant selection was limited to those aged over 60, without cognitive impairmentor acute psychotic problems. In total 90 senior citizens were selected, equally representing three living arrangements- living in institutions or old age homes, living with family and living without family. At the beginning of the interview, the elderly couples were asked to complete the sociodemographic details, and the Depression Scale. Then a semi- structured interview was conducted. And the elderly couples were interviewed separately. Only one spouse was considered for the study either male or female from a family. Each interview lasted approximately 30 minutes. The personal and socio-economic variables were considered independent while the depression was a dependent variable (measured by Beck Depression Inventory, 1961). The personal variables were measured with self-prepared interview schedule.

\section{Results and Discussion}

\section{Personal and socio-economic profile of respondents}

The personal data consists of basic information regarding the respondent general profile which includes age, gender, marital status, educational level, physical dependency and health status across the place of residence of elderly. Almost half of the respondents were aged between 70-79 years followed by 60-69 years and 80 years and above. Of the total respondents more than 60 percent were males and nearly half of the respondents were living with the spouse. Most of the elderly were educated upto Primary level followed by matriculate. It was found that nearly half of the respondents were physically independent i.e they rarely require the assistance of family members. None of the respondents had any serious impairment. Socio-economic profile was measured in four domains i.e. leisure time utilization, economic dependency, family support system, exposure to media. It was found that more than half of respondents had high leisure time utilization. Nearly quarters of them were pension holders and others were dependent either on children or institutions in which they were residing. Most of the elderly had average level of family support system. There was moderate to high level of media exposure in majority of cases (Table 1 and 2).

\section{Mean comparison of depression levels on the basis of living arrangements}

The mean differences in table 3 highlights that there was statistically significant differences in depression levels of elderly residing in institution, with family and without family. The highest mean depression level was found in those elderly respondents who were living without family followed by those living in institution (14.8). It was found that mean depression level was lowest among elderly living with family (21.1). The means differed significantly within the living arrangements.

Mean comparison of depression levels on the basis of gender

The mean comparison of depression levels of male and females in table 4 highlights that male respondents had high level of depression (22.8) as compared to their female counterparts (17.0). The mean depression level differences were high and statistically significant between male and female.

In conclusion, the statistical findings regarding the depression level among the elderly residing in different settings in Panchkula city indicates that based on the Beck Depression Inventory (1961) most of the respondents had moderate and borderline depression and the mean depression level is lying between near to borderline depression. 
Table.1 Distribution of respondents on the basis of personal and socio-economic variables

\begin{tabular}{|c|c|c|c|}
\hline $\begin{array}{l}\text { Place of Residence } \\
\text { Personal } \\
\text { Variables }\end{array}$ & $\begin{array}{l}\text { Respondents } \\
(\mathbf{N}=90)\end{array}$ & $\begin{array}{l}\text { Place of residence } \\
\text { Socio-eco. Profile }\end{array}$ & $\begin{array}{l}\text { Respondents } \\
\quad(\mathbf{N}=90)\end{array}$ \\
\hline Age & & Leisure Time Utilization & \\
\hline $\begin{array}{l}60-69 \\
70-79 \\
80 \text { and above }\end{array}$ & $\begin{array}{c}41(45.5) \\
44(48.8) \\
5(5.55)\end{array}$ & $\begin{array}{l}\text { Rare involvement } \\
\text { Moderate involvement } \\
\text { Highly involvement }\end{array}$ & $\begin{array}{l}- \\
35(38.8) \\
55(61.1)\end{array}$ \\
\hline Gender & & Economic dependency & \\
\hline $\begin{array}{l}\text { Male } \\
\text { Female }\end{array}$ & $\begin{array}{c}61(67.7) \\
29(32.2)\end{array}$ & $\begin{array}{l}\text { Dependent on Institutions } \\
\text { Dependent on Children } \\
\text { Pension Holder }\end{array}$ & $\begin{array}{l}31(34.4) \\
36(40.0) \\
23(25.5)\end{array}$ \\
\hline Marital Status & & Family Support System & \\
\hline $\begin{array}{l}\text { Widow } \\
\text { Widower } \\
\text { Both spouse }\end{array}$ & $\begin{array}{l}7(7.77) \\
31(34.4) \\
52(57.7)\end{array}$ & $\begin{array}{l}\text { Low } \\
\text { Moderate } \\
\text { High }\end{array}$ & $\begin{array}{l}11(12.2) \\
63(70.0) \\
16(17.7)\end{array}$ \\
\hline Educational level & & Media Exposure & \\
\hline $\begin{array}{l}\text { Illiterate } \\
\text { Primary } \\
\text { Matriculate } \\
\text { Senior secondary } \\
\text { Graduate }\end{array}$ & $\begin{array}{l}1(1.11) \\
47(52.2) \\
17(18.8) \\
15(16.6) \\
10(11.1)\end{array}$ & $\begin{array}{l}\text { Low } \\
\text { Moderate } \\
\text { High }\end{array}$ & $\begin{array}{l}3(3.3) \\
47(52.2) \\
40(44.4)\end{array}$ \\
\hline Physical Dependency & & - & - \\
\hline $\begin{array}{l}\text { Totally dependent } \\
\text { Partially dependent } \\
\text { Dependent for heavy work } \\
\text { Independent }\end{array}$ & $\begin{array}{l}- \\
23(25.5) \\
23(25.5) \\
44(48.8)\end{array}$ & - & - \\
\hline Health Status & & - & - \\
\hline $\begin{array}{l}\text { Impairment } \\
\text { Average } \\
\text { Good } \\
\text { Very good }\end{array}$ & $\begin{array}{l}- \\
38(42.2) \\
20(22.2) \\
32(35.5)\end{array}$ & - & - \\
\hline
\end{tabular}

*Figures in parenthesis indicates percentage 
Table.2 Depression level among the respondents

\begin{tabular}{|l|c|c|}
\hline \multicolumn{1}{|c|}{ Frequency \& Mean } & Respondents(N=90) & Mean+SD \\
Depression & & \\
\hline Normal (1-10) & $14(15.5)$ & \multirow{2}{*}{$20.94 \pm 9.75$} \\
\hline $\begin{array}{l}\text { Mild Mood Disturbances(11- } \\
\text { 16) }\end{array}$ & $9(10.0)$ & \\
\hline Borderline Depression(17-20) & $25(27.7)$ & \\
\hline Moderate Depression(21-30) & $27(30.0)$ & \\
\hline Severe Depression(31-40) & $15(16.6)$ \\
\hline
\end{tabular}

*Figures in parenthesis indicates percentage

Table.3 Comparison of depression levels across living arrangements

\begin{tabular}{|l|c|c|c|c|}
\hline \multirow{3}{*}{ Living Arrangements } & Institution & With family & Without family & F value \\
\cline { 2 - 5 } Depression & Mean \pm SD & Mean \pm SD & Mean \pm SD & \multirow{1}{*}{$10.7^{*} *$} \\
\cline { 2 - 5 } & $21.1 \pm 7.0^{\mathrm{a}}$ & $14.8 \pm 11.1^{\mathrm{c}}$ & $26.2 \pm 7.1^{\mathrm{b}}$ & \\
\hline
\end{tabular}

**Significant at $1 \%$ level of significance

Table.4 Comparison of depression levels across gender in Panchkula

\begin{tabular}{|c|c|c|c|}
\hline \multirow[t]{3}{*}{ Place of Residence } & Male & Female & t- value \\
\hline & Mean \pm SD & Mean \pm SD & \multirow[t]{2}{*}{$3.49 *$} \\
\hline & $22.8 \pm 9.9$ & $17.0 \pm 8.1$ & \\
\hline
\end{tabular}

*Significant at 5\% level of significance

Further, the mean comparison of depression across gender elucidates that male experienced higher depression then the female counterparts. In case of mean comparison of depression across the different living arrangement highlights that highest level of depression is experienced by those respondents who were living alone followed by residing in institutions. Least level of depression was experienced by those living with family according to the research undertaken. The results obtained are in congruence with the findings of the study conducted by Chou and Chi (2000). It was observed that those elderly residing with family were hesitant while responding to the questions of researcher. While, elderly who were interviewed during their visit to parks, community centres were more open and willing to be interviewed.

\section{References}

Chou, K. L. and Chi, I. (2000) Comparison between elderly Chinese living alone and those living with others

Ganatra, H.A., Zafar, S.N., Qidwai, W. and Rozi, S. (2008) Prevalence and 
predictors of depression among an elderly population of elderly population of Pakistan. Aging and Mental Health, 12(3).

Kennedy, G.J. (1996) The epidemiology of late-life depression. In: Kennedy G.J., editor. Suicide and depression in late life: Crititcal Issues in treatment, research and public policy. New York: John Wiley and Sons; 23-37.

Mubeen, S.M., Henry, D. and Qureshi, S.N. (2012) Prevalence of depression among community dwelling elderly in Karachi, Pakistan. Iran J. Psychiatry Behav. Sci., 6(2).

Rasquinha, D.M. and Acharya, Y.T.B. (2012) Gender differences in depression among
Institutionalized and noninstitutionalized elderly. Global Research Analysis, 1(5).

Warnick, J. (1995) Listening with different ears: Counseling people over sixty. Ft. Bragg CA: QED Press.

Weissman, M.M., Bland. R.C., Canino, G.J., Faravelli, C. and Greenwald, S. (1996) Cross-national epidemiology of major depression and bipolar disorder. JAMA, 276: 293-299.

World Health Organization, (2012) Depression. WHO. http://www.who.int/mental_health/ management/depression/definition/en/in dex.htm. access on 6.11.18

\section{How to cite this article:}

Shamli Rana, Shallu Rana and Chandra Kala Singh. 2019. Depression and Living Patterns in Old age. Int.J.Curr.Microbiol.App.Sci. 8(03): 48-53.

doi: https://doi.org/10.20546/ijcmas.2019.803.007 